\title{
Dyadobacter hamtensis sp. nov., from Hamta glacier, located in the Himalayas, India
}

\author{
Correspondence \\ S. Shivaji \\ shivas@ccmb.res.in
}

\author{
P. Chaturvedi, G. S. N. Reddy and S. Shivaji \\ Centre for Cellular and Molecular Biology, Uppal Road, Hyderabad 500 007, India
}

\begin{abstract}
Strain HHS $11^{\top}$ was isolated from a water sample collected from the snout of Hamta glacier located in the Himalayan mountain ranges of India. Phenotypic, chemotaxonomic and phylogenetic analyses established the affiliation of the isolate to the genus Dyadobacter. HHS $11^{\top}$ possessed 96 and $95 \% 16 \mathrm{~S}$ rRNA gene sequence similarity with respect to Dyadobacter crusticola and Dyadobacter fermentans, respectively. Furthermore, strain $\mathrm{HHS} 11^{\top}$ differs from $D$. crusticola and $D$. fermentans in a number of phenotypic characteristics. These data suggest that strain HHS $11^{\top}$ represents a novel species of the genus Dyadobacter, for which the name Dyadobacter hamtensis sp. nov. is proposed. The type strain is $\mathrm{HHS} 11^{\top}$ $\left(=\mathrm{JCM} 12919^{\top}=\right.$ MTCC $\left.7023^{\top}\right)$.
\end{abstract}

The genus Dyadobacter Chelius and Triplett 2000 was created within the Flexibacter group to include Gramnegative rods that occur in pairs in young cultures but form chains of coccoid cells in older cultures. The cells are nonmotile, oxidase- and catalase-positive, aerobic, capable of fermenting glucose and sucrose, do not hydrolyse cellulose or starch and produce a flexirubin-like pigment. These micro-organisms have a DNA G $+\mathrm{C}$ content of $48 \mathrm{~mol} \%$ and are phylogenetically closely related to the genera Runella and Microscilla (Chelius \& Triplett, 2000). To date, only two species of the genus, namely Dyadobacter fermentans, isolated from surface-sterilized Zea mays stems (Chelius \& Triplett, 2000), and Dyadobacter crusticola, from biological soil crusts (Reddy and Garcia-Pichel, 2005), have been described. In this report, strain HHS $11^{\mathrm{T}}$, an isolate from the Hamta glacier in the Himalayan mountain ranges in India, has been identified, on the basis of phenotypic, chemotaxonomic and phylogenetic analyses, as representing a novel species of the genus Dyadobacter.

Strain HHS $11^{\mathrm{T}}$ was isolated from a water sample collected from the 'snout' of the Hamta glacier located at a height of $4270 \mathrm{~m}$ above sea level. The sample was processed as described previously (Shivaji et al., 2005b) and pure colonies of bacteria were isolated by repeated streaking on plates containing nutrient agar $[0 \cdot 5 \%, \mathrm{w} / \mathrm{v}$, peptone (HiMedia); $0 \cdot 3 \%$, w/v, beef extract (HiMedia); $0.5 \%$ w/v, NaCl; $1.5 \%$, $\mathrm{w} / \mathrm{v}$, agar; $\mathrm{pH} 7 \cdot 0]$. The plates were incubated at $22^{\circ} \mathrm{C}$ for 3 days.

Nutrient agar medium was used for maintaining strain HHS $11^{\mathrm{T}}$ and for the determination of growth at various

The GenBank/EMBL/DDBJ accession number for the 16S rRNA gene sequence of strain $\mathrm{HHS} 11^{\top}$ is AJ619979. temperatures, at different $\mathrm{pH}$ values and in the presence of various concentrations of $\mathrm{NaCl}$ (Shivaji et al., 1989). Phenotypic characteristics such as colony morphology, cell morphology, motility, various enzyme activities and gas production (Hugh \& Leifson, 1953), growth in various media, such as Ayers' and R2A (Ayers et al., 1919; Chelius \& Triplett, 2000), and sensitivity to antibiotics at $22{ }^{\circ} \mathrm{C}$ were ascertained as described previously (Shivaji et al., 2004, 2005a) by using standard methods (Lanyi, 1987; Smibert \& Krieg, 1994). Minimal medium $\left[\mathrm{K}_{2} \mathrm{HPO}_{4}, 1 \cdot 05 \%\right.$, w/v; $\mathrm{KH}_{2} \mathrm{PO}_{4}, 0 \cdot 45 \%$, w/v; $(\mathrm{NH} 4)_{2} \mathrm{SO}_{4}, 0 \cdot 1 \%$, w/v; agar, $1 \cdot 5 \%$, $\mathrm{w} / \mathrm{v}$ ] was used to evaluate the ability of the culture to assimilate various carbon compounds $(0 \cdot 5 \%$, w/v) when provided as the only carbon source. The presence of a flexirubin-like pigment was tested according to the method of Weeks (1981). Fatty acid methyl esters were prepared according to the method of Sato \& Murata (1988) and analysed by GC (Shivaji et al., 2004; 2005a). The G+C content of the DNA was determined by the spectrophotometric method (Shivaji et al., 1989). D. fermentans NS $114^{\mathrm{T}}$ was used as a reference strain in studies relating to morphology, biochemical tests and the identification of fatty acids.

To establish the phylogenetic position of strain HHS $11^{\mathrm{T}}$, DNA was purified and the 16S rRNA gene was amplified and sequenced as described previously (Shivaji et al., 2000). The almost-complete sequence of 1466 bases was manually aligned against the sequences of closely related species of Dyadobacter and other related genera using CLUSTAL W (Thompson et al., 1994) (Fig. 1) and phylogenetic affiliations were inferred using SEQBOOT, DNADIST, FITCH, DNAPARS and neighbour-joining, according to PHYLIP (Felsenstein, 1993). The Kimura two-parameter method was used for DNA distance calculation (Kimura, 1980), and 


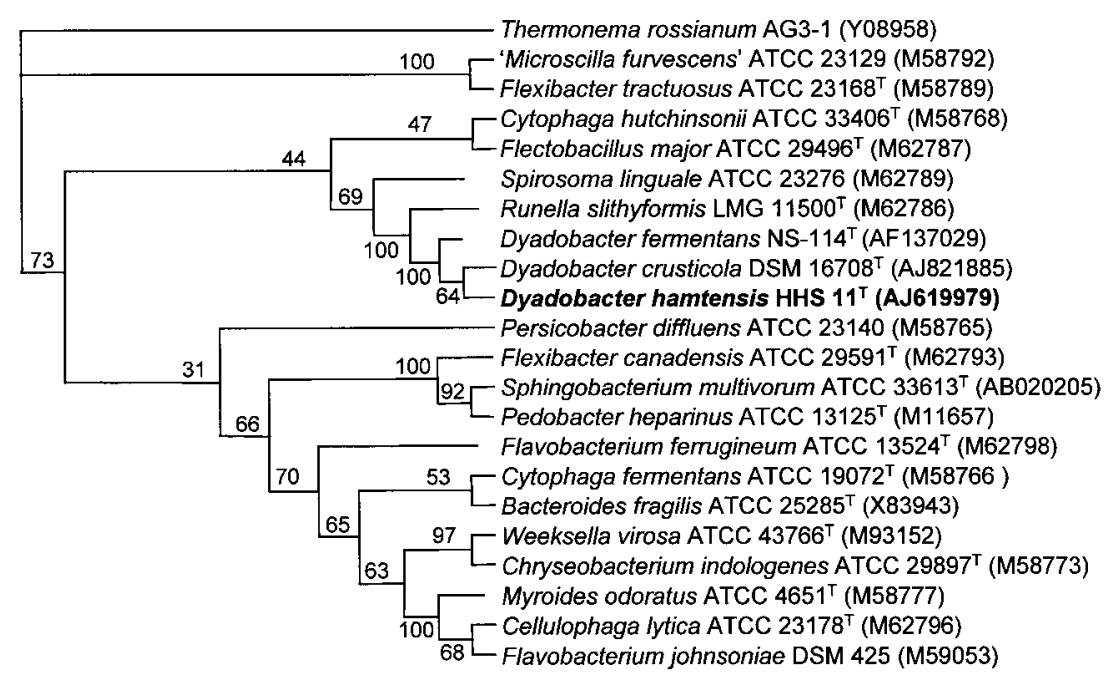

Fig. 1. Neighbour-joining tree, based on 16S rRNA gene sequences (1455 bases), showing the phylogenetic relationship between $D$. hamtensis sp. nov. and species of the genera Dyadobacter, Runella, Spirosoma, Flectobacillus and Cytophaga and other closely related genera. bootstrap values were generated for 1000 replications of the data. In all cases, the input order of species added to the topology being constructed was randomized with the jumble option with a random seed of 7 and 10 replications. Majority rule $(50 \%)$ consensus trees were constructed (Page, 1996).

Strain HHS $11^{\mathrm{T}}$ conforms to the characteristics of the genus Dyadobacter in that it is Gram-negative, rod-shaped in both exponential and stationary phases, appears in pairs, is nonmotile, aerobic, oxidase- and catalase-positive, ferments glucose but not sucrose, does not hydrolyse starch, has a DNA G $+\mathrm{C}$ content of $49 \mathrm{~mol} \%$ and is phylogenetically related to Runella and Microscilla (see Fig. 1, Table 1 and the species description for more details). In addition, HHS $11^{\mathrm{T}}$ produces a flexirubin-like yellow-coloured pigment, a characteristic feature of the genus Dyadobacter. The pigment was extracted according to the method of Weeks (1981) and the spectrum was obtained using a UV-visible spectrophotometer (UV-1601; Shimadzu): the pigment exhibited peaks at 422, 458 and $476 \mathrm{~nm}$ when extracted in ethanol. The addition of alkali $(20 \% \mathrm{KOH})$ changed the colour of the pigment to orange and also broadened the peak, thus confirming that it is a flexirubin-type pigment (Weeks, 1981).

The affiliation of strain HHS $11^{\mathrm{T}}$ to the genus Dyadobacter is further supported by the phylogenetic analysis based on the 16S rRNA gene sequence, which indicates that HHS $11^{\mathrm{T}}$ is related to the type strains of Dyadobacter species with validly published names, namely D. fermentans $\mathrm{NS}_{114}{ }^{\mathrm{T}}$ and $D$. crusticola $\mathrm{C} 183-8^{\mathrm{T}}$. At the $16 \mathrm{~S}$ rRNA gene level, strain HHS $11^{\mathrm{T}}$ exhibits only $96 \%$ similarity to $D$. crusticola $\mathrm{C} 183-8^{\mathrm{T}}$ and $95 \%$ similarity to $D$. fermentans $\mathrm{NS}_{11}{ }^{\mathrm{T}}$. This difference of $>4 \%$ at the $16 \mathrm{~S}$ rRNA gene sequence level between HHS $11^{\mathrm{T}}$ and the nearest phylogenetic neighbour suggests that strain HHS $11^{\mathrm{T}}$ represents a novel species, according to the accepted criteria (Stackebrandt \& Goebel, 1994). DNADNA hybridization between strain HHS $11^{\mathrm{T}}$ and the nearest phylogenetic neighbours was not attempted since strains differing by $>2.5 \%$ at the $16 \mathrm{~S}$ rRNA gene level are unlikely to exhibit $>70 \%$ similarity at whole-genome level (Stackebrandt \& Goebel, 1994). The assignment of novel species status to HHS $11^{\mathrm{T}}$ is further strengthened on the basis of the differences the strain exhibits with respect to both of the Dyadobacter species with validly published names (Table 1). Distinct differences are also observed in the fatty acid composition of strain HHS $11^{\mathrm{T}}$, D. crusticola CP183-8 $8^{\mathrm{T}}$ and D. fermentans $\mathrm{NS} 114^{\mathrm{T}}$. In strain HHS $11^{\mathrm{T}}$, the predominant fatty acids are iso- $\mathrm{C}_{15: 1}$, iso- $\mathrm{C}_{15: 0}, \mathrm{C}_{16: 1} \omega 5 c$, $\mathrm{C}_{16: 1} \omega 7 c, \mathrm{C}_{16: 0}$ and iso- $\mathrm{C}_{17: 0} 3-\mathrm{OH}$. In D. crusticola CP183$8^{\mathrm{T}}$, these fatty acids were also present; however, the level of iso- $\mathrm{C}_{15 \text { :0 }}$ was lower and the level of $\mathrm{C}_{16: 1} \omega 7 c$ was higher. The fatty acid composition of D. fermentans $\mathrm{NS}_{114}{ }^{\mathrm{T}}$ was very similar to that of strain HHS $11^{\mathrm{T}}$ except that it contains iso- $\mathrm{C}_{15: 0} 3-\mathrm{OH}$ and lacks $\mathrm{C}_{18: 1}$ (Table 2). Thus, on the basis of the above phenotypic, chemotaxonomic and phylogenetic differences, it is proposed that strain HHS $11^{\mathrm{T}}$ be assigned as the type strain of a novel species of the genus Dyadobacter, for which the name Dyadobacter hamtensis sp. nov. is proposed.

\section{Description of Dyadobacter hamtensis sp. nov.}

Dyadobacter hamtensis (ham.ten'sis. N.L. masc. adj. hamtensis pertaining to the Hamta glacier).

Colonies of strain HHS $11^{\mathrm{T}}$ on nutrient agar medium are round (2-3 $\mathrm{mm}$ in diameter) and light yellow. Cells are aerobic, Gram-negative rods and are non-motile. Growth occurs between 10 and $37^{\circ} \mathrm{C}$ and at $\mathrm{pH} \mathrm{6-8,} \mathrm{but} \mathrm{not} \mathrm{at}$ $\mathrm{pH}$ 10. The optimum temperature and $\mathrm{pH}$ for growth are $22{ }^{\circ} \mathrm{C}$ and $\mathrm{pH} 7$. Growth occurs in the presence of $11.6 \%$ $\mathrm{NaCl}$. Growth occurs on nutrient agar medium, Ayers' agar and R2A medium. The strain is positive for catalase, oxidase, phosphatase, arginine decarboxylase and $\beta$-galactosidase, but negative for gelatinase, urease, lipase, lysine decarboxylase, arginine dihydrolase, utilization of citrate, $\mathrm{H}_{2} \mathrm{~S}$ production, the methyl red test, the indole test, the VogesProskauer test, hydrolysis of aesculin, hydrolysis of starch 
Table 1. Phenotypic characteristics that differentiate $D$. hamtensis sp. nov., D. crusticola and $D$. fermentans

All three species have the same colony shape and all stain Gramnegative, are non-motile, rod-shaped, positive for catalase, oxidase and $\beta$-galactosidase, tolerate $1 \% \mathrm{NaCl}$, grow at $\mathrm{pH} 6-8$, grow at 25 and $30^{\circ} \mathrm{C}$, grow in $\mathrm{R} 2 \mathrm{~A}$ medium, utilize D-glucose, D-cellobiose, sucrose, D-trehalose, D-raffinose, D-lactose and inulin and are resistant to bacitracin $(10 \mu \mathrm{g})$, nitrofurantoin $(300 \mu \mathrm{g})$, penicillin $(10 \mu \mathrm{g})$, vancomycin $(10 \mu \mathrm{g})$ and erythromycin $(15 \mu \mathrm{g})$. All are negative for urease, gelatinase, starch hydrolysis, citrate utilization, $\mathrm{H}_{2} \mathrm{~S}$ production, nitrate reduction, the methyl red test, indole production, the Voges-Proskauer test, arginine dihydrolase, acid production from Dlactose, D-galactose, D-ribose, growth at $\mathrm{pH} 4$ and $\mathrm{pH} 10$, and the utilization of sodium succinate, starch and pyruvate. All are sensitive to doxycyline $(30 \mu \mathrm{g})$ and tetracycline $(30 \mu \mathrm{g})$. Symbols: + , positive; - , negative; $-/+$, variable; $\mathrm{W}$, weak reaction; NA, data not available. Data for HHS $11^{\mathrm{T}}$ and D. fermentans NS- $114^{\mathrm{T}}$ were obtained in the present study; data for D. crusticola $\mathrm{C} 183-8^{\mathrm{T}}$ were taken from Reddy \& Garcia-Pichel (2005).

\begin{tabular}{|c|c|c|c|}
\hline Characteristic & $\begin{array}{l}\text { D. hamtensis } \\
\text { HHS } 11^{\mathrm{T}}\end{array}$ & $\begin{array}{l}\text { D. crusticola } \\
\mathrm{C}^{183-8^{\mathrm{T}}}\end{array}$ & 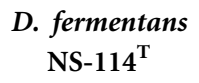 \\
\hline Colony size (mm) & $2-3$ & NA & $2-3$ \\
\hline Colony colour & Light yellow & Yellow & Orange \\
\hline Cell shape & Long rods & Rods & Rods \\
\hline Growth at $5^{\circ} \mathrm{C}$ & - & + & - \\
\hline Growth at $37^{\circ} \mathrm{C}$ & + & - & + \\
\hline $\begin{array}{l}\text { Maximum growth } \\
\text { temp. }\left({ }^{\circ} \mathrm{C}\right)\end{array}$ & 37 & 25 & 37 \\
\hline $\begin{array}{l}\text { Fermentative } \\
\text { metabolism }\end{array}$ & + & - & + \\
\hline \multicolumn{4}{|l|}{ Growth on: } \\
\hline Peptone & + & NA & + \\
\hline Ayers' agar & + & $\mathrm{NA}$ & + \\
\hline Lipase activity & - & + & - \\
\hline $\begin{array}{l}\text { Phosphatase } \\
\text { activity }\end{array}$ & + & + & - \\
\hline Aesculin hydrolysis & - & + & + \\
\hline $\begin{array}{l}\text { Lysine decarboxy- } \\
\text { lase activity }\end{array}$ & - & - & + \\
\hline $\begin{array}{l}\text { Arginine decarboxy- } \\
\text { lase activity }\end{array}$ & + & - & - \\
\hline \multicolumn{4}{|l|}{$\begin{array}{l}\text { Oxidation/fermen- } \\
\text { tation }^{*}\end{array}$} \\
\hline Glucose & + & - & F \\
\hline Sucrose & - & - & $\mathrm{F}$ \\
\hline \multicolumn{4}{|l|}{$\begin{array}{l}\text { Acid production } \\
\text { from: }\end{array}$} \\
\hline D-Glucose & + & - & + \\
\hline Sucrose & - & - & + \\
\hline D-Fructose & - & + & - \\
\hline D-Maltose & - & - & + \\
\hline D-Arabinose & + & - & + \\
\hline D-Xylose & + & - & + \\
\hline \multicolumn{4}{|l|}{$\begin{array}{l}\text { Carbon-source } \\
\text { utilization }\end{array}$} \\
\hline D-Galactose & + & - & + \\
\hline
\end{tabular}

Table 1. cont.

\begin{tabular}{|c|c|c|c|}
\hline Characteristic & $\begin{array}{c}\text { D. hamtensis } \\
\text { HHS } 11^{\mathrm{T}}\end{array}$ & $\begin{array}{l}\text { D. crusticola } \\
{\mathrm{C} 183-8^{\mathrm{T}}}^{-}\end{array}$ & 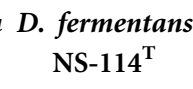 \\
\hline L-Sorbose & + & - & + \\
\hline D-Rhamnose & - & - & + \\
\hline D-Arabinose & - & - & + \\
\hline L-Arabinose & + & - & + \\
\hline L-Melibiose & - & + & + \\
\hline D-Fructose & - & - & + \\
\hline D-Mannose & - & - & + \\
\hline D-Xylose & - & + & + \\
\hline D-Mannitol & - & $-1+$ & + \\
\hline Glycerol & + & - & $\mathrm{W}$ \\
\hline D-Ribose & - & + & - \\
\hline Lactic acid & + & + & - \\
\hline D-Adonitol & + & - & - \\
\hline D-Sorbitol & - & + & $\mathrm{W}$ \\
\hline Dulcitol & - & + & $\mathrm{w}$ \\
\hline Dextran & + & - & - \\
\hline Citric acid & + & - & - \\
\hline Sodium acetate & + & - & + \\
\hline Cellulose & + & - & - \\
\hline myo-Inositol & - & + & + \\
\hline Fumarate & + & - & + \\
\hline Malonate & + & - & + \\
\hline Tartrate & + & - & + \\
\hline \multicolumn{4}{|l|}{ Amino acids } \\
\hline L-Glycine & + & - & + \\
\hline L-Alanine & + & - & - \\
\hline L-Valine & + & - & - \\
\hline L-Leucine & + & - & - \\
\hline L-Isoleucine & + & - & - \\
\hline L-Serine & + & - & - \\
\hline L-Threonine & + & - & - \\
\hline L-Lysine & + & - & + \\
\hline L-Arginine & + & - & + \\
\hline L-Glutamic acid & + & - & - \\
\hline L-Aspartic acid & + & - & - \\
\hline L-Glutamine & + & - & + \\
\hline L-Asparagine & + & - & - \\
\hline L-Methionine & + & - & + \\
\hline L-Cysteine & + & - & - \\
\hline L-Tyrosine & + & - & - \\
\hline L-Phenylalanine & + & - & - \\
\hline L-Tryptophan & + & - & + \\
\hline L-Proline & + & - & - \\
\hline L-Histidine & + & - & - \\
\hline \multicolumn{4}{|l|}{$\begin{array}{l}\text { Effect of antibiotics } \\
(\mu \mathrm{g} \text { per disc }) \dagger\end{array}$} \\
\hline $\begin{array}{l}\text { Ciprofloxacin } \\
(30)\end{array}$ & $S$ & $\mathrm{R}$ & $\mathrm{S}$ \\
\hline Colistin (10) & $\mathrm{S}$ & $\mathrm{R}$ & $\mathrm{R}$ \\
\hline Novobiocin (30) & $\mathrm{R}$ & $\mathrm{S}$ & $\mathrm{R}$ \\
\hline $\begin{array}{l}\text { Chloramphenicol } \\
\text { (30) }\end{array}$ & S & $\mathrm{R}$ & $\mathrm{R}$ \\
\hline Streptomycin (25) & $S$ & $\mathrm{R}$ & $\mathrm{R}$ \\
\hline
\end{tabular}


Table 1. cont.

\begin{tabular}{|cccc|}
\hline Characteristic & $\begin{array}{c}\text { D. hamtensis } \\
\text { HHS 11 }^{\mathbf{T}}\end{array}$ & $\begin{array}{c}\text { D. crusticola } \\
\text { C183-8 }^{\mathbf{T}}\end{array}$ & $\begin{array}{c}\text { D. fermentans } \\
\text { NS-114 }^{\mathbf{T}}\end{array}$ \\
\hline $\begin{array}{c}\text { Rifampicin } \\
\left(25 \mu \mathrm{g} \mathrm{ml}^{-1}\right)\end{array}$ & $\mathrm{S}$ & $\mathrm{S}$ & $\mathrm{R}$ \\
$\begin{array}{c}\text { Trimethoprim } \\
\left(25 \mu \mathrm{g} \mathrm{ml}^{-1}\right)\end{array}$ & $\mathrm{S}$ & $\mathrm{R}$ & $\mathrm{R}$ \\
$\begin{array}{c}\text { DNA G }+\mathrm{C} \\
\text { content }(\mathrm{mol} \%)\end{array}$ & 49 & 48 & 48 \\
\hline
\end{tabular}

${ }^{\star} \mathrm{F}$, Fermentation positive.

$\dagger \mathrm{R}$, Resistant; S, sensitive.

and reduction of nitrate to nitrite. Acid is produced from Dxylose, D-arabinose and D-glucose, but not from D-ribose, D-fructose, D-galactose, L-rhamnose, sucrose, D-lactose, Dmaltose or D-mannose. Utilizes L-arabinose, D-glucose, Dgalactose, L-sorbose, sucrose, $\mathrm{N}$-acetylglucosamine, methyl $\alpha$-D-mannoside, methyl $\alpha$-D-glucoside, L-fucose, melezitose, D-cellobiose, D-trehalose, D-lactose, D-raffinose, cellulose, amygdalin, dextran, glycogen, arbutin, salicin, glycerol, Derythritol, D-adonitol, citrate, malonate, lactic acid, citric acid, 2-ketogluconate, inulin, sodium formate, sodium fumarate, sodium malate, sodium tartrate, sodium acetate, PEG, L-glycine, L-alanine, L-valine, L-leucine, L-isoleucine, L-serine, L-threonine, L-lysine, L-arginine, L-glutamic acid, L-aspartic acid, L-glutamine, L-asparagine, L-methionine, L-cysteine, L-tyrosine, L-phenylalanine, L-tryptophan, Lproline, L-histidine and L-creatinine as sole carbon sources.

Table 2. Fatty acid composition (\%) of $D$. hamtensis sp. nov. HHS $11^{\top}$, D. crusticola CP183-8 ${ }^{\top}$ and $D$. fermentans NS-114

D. hamtensis sp. nov. HHS $11^{\mathrm{T}}$ and D. fermentans NS-114 ${ }^{\mathrm{T}}$ were grown in $\mathrm{R} 2 \mathrm{~A}$ medium at $25^{\circ} \mathrm{C}$ for the determination of the fatty acid composition. Data for D. crusticola CP183- $8^{\mathrm{T}}$ are from Reddy \& Garcia-Pichel (2005). -, Fatty acid not present.

\begin{tabular}{|c|c|c|c|}
\hline Fatty acid & $\begin{array}{l}\text { D. hamtensis } \\
\text { HHS } 11^{\mathrm{T}}\end{array}$ & $\begin{array}{l}\text { D. crusticola } \\
\text { CP183-8 }^{\mathrm{T}}\end{array}$ & $\begin{array}{l}\text { D. fermentans } \\
\text { NS } 114^{\mathrm{T}}\end{array}$ \\
\hline $\mathrm{C}_{14: 0}$ & $1 \cdot 23$ & $1 \cdot 4$ & - \\
\hline iso- $\mathrm{C}_{15: 1}$ & $3 \cdot 7$ & $1 \cdot 5$ & - \\
\hline iso- $\mathrm{C}_{15: 0}$ & $24 \cdot 69$ & $13 \cdot 4$ & $22 \cdot 85$ \\
\hline $\mathrm{C}_{16: 1} \omega 5 c$ & $19 \cdot 75$ & $21 \cdot 4$ & $14 \cdot 28$ \\
\hline $\mathrm{C}_{16: 1} \omega 7 c$ & $14 \cdot 81$ & $41 \cdot 2$ & $28 \cdot 57$ \\
\hline $\mathrm{C}_{16: 0}$ & $8 \cdot 64$ & $12 \cdot 4$ & $5 \cdot 71$ \\
\hline iso- $\mathrm{C}_{15: 0} 3-\mathrm{OH}$ & - & $2 \cdot 4$ & $2 \cdot 85$ \\
\hline Unknown & - & $0 \cdot 3$ & - \\
\hline $\mathrm{C}_{16: 0} 3-\mathrm{OH}$ & $2 \cdot 46$ & $2 \cdot 2$ & $2 \cdot 85$ \\
\hline $\mathrm{C}_{18: 0}$ & - & $0 \cdot 16$ & - \\
\hline $\mathrm{C}_{18: 1}$ & $2 \cdot 46$ & $0 \cdot 83$ & - \\
\hline iso- $\mathrm{C}_{17: 0} 3-\mathrm{OH}$ & $22 \cdot 22$ & $2 \cdot 9$ & $22 \cdot 85$ \\
\hline
\end{tabular}

Does not utilize D-rhamnose, D-arabinose, L-melibiose, D-fructose, D-mannose, D-mannitol, D-xylose, L-xylose, D-ribose, D-maltose, D-sorbitol, dulcitol, myo-inositol, gluconate, hydroxybutyric acid, sodium succinate, sodium pyruvate, thioglycolate, starch, methanol or agar as sole carbon sources. Cells are sensitive to ( $\mu$ g per disc) ciprofloxacin (30), cefoperazone (75), cephotaxime (10), doxycycline (30), colistin (10), sulphamethazole (50), kanamycin (30), tetracycline (30), nalidixic acid (30), chloramphenicol (25), rifampicin (25), streptomycin (10), trimethoprim (25), norfloxacin (10), lomefloxacin (30), tobramycin (15) and amikacin (30), but resistant to cotrimoxazole (25), roxithromycin (30), nitrofurantoin (300), penicillin (10), cefuroxime (20), lincomycin (20), cefazolin (30), novobiocin (30), ampicillin (25 $\left.\mu \mathrm{g}^{-1}\right)$, amoxicillin (30), bacitracin (10), vancomycin (10) and erythromycin (15). The pigment is flexirubin-like. The $\mathrm{G}+\mathrm{C}$ content of the DNA is $49 \mathrm{~mol} \%$. The major cellular fatty acids are $\mathrm{C}_{14: 0}$, iso- $\mathrm{C}_{15: 0}$, iso- $\mathrm{C}_{15: 1}, \mathrm{C}_{16: 1} \omega 5 c, \mathrm{C}_{16: 0}, \mathrm{C}_{16: 1} \omega 7 c, \mathrm{C}_{16: 0} 3-\mathrm{OH}, \mathrm{C}_{18: 1}$ and iso- $\mathrm{C}_{17: 0} 3-\mathrm{OH}$.

The type strain, HHS $11^{\mathrm{T}}\left(=\mathrm{JCM} 12919^{\mathrm{T}}=\operatorname{MTCC} 7023^{\mathrm{T}}\right)$, was isolated from a glacial water sample.

\section{Acknowledgements}

We thank the Department of Biotechnology, Government of India, New Delhi, India, for funding. Our special thanks go to Sri Deepak Srivastava, Sri Siddhartha Swaroop and his team from the Glaciology Department of Geological Survey of India, Faridabad, India, for their help with collection of the samples.

\section{References}

Ayers, S. H., Rupp, P. \& Johnson, W. T. (1919). A study of the alkali forming bacteria in milk. U S Dep Agric Bull 782.

Chelius, M. K. \& Triplett, W. E. (2000). Dyadobacter fermentans gen. nov., sp. nov., a novel Gram-negative bacterium isolated from surface-sterilized Zea mays stems. Int J Syst Evol Microbiol 50, 751-758.

Felsenstein, J. (1993). PHYLIP (phylogeny inference package), version 3.5c. Distributed by the author. Department of Genome Sciences, University of Washington, Seattle, USA.

Hugh, R. \& Leifson, E. (1953). The taxonomic significance of fermentative versus oxidative metabolism of carbohydrates by various gram negative bacteria. J Bacteriol 66, 24-26.

Kimura, M. (1980). A simple method for estimating evolutionary rates of base substitutions through comparative studies of nucleotide sequences. J Mol Evol 16, 111-120.

Lanyi, B. (1987). Classical and rapid identification methods for medically important bacteria. Methods Microbiol 19, 1-67.

Page, R. D. M. (1996). TreeView: an application to display phylogenetic trees on personal computers. Comput Appl Biosci 12, 357-358.

Reddy, G. S. N. \& Garcia-Pichel, F. (2005). Dyadobacter crusticola sp. nov., from biological soil crusts in the Colorado Plateau, USA, and an emended description of the genus Dyadobacter Chelius and Triplett 2000. Int J Syst Evol Microbiol 55, 1295-1299.

Sato, N. S. \& Murata, N. (1988). Membrane lipids. Methods Enzymol 167, 251-259. 
Shivaji, S., Rao, N. S., Saisree, L., Sheth, V., Reddy, G. S. \& Bhargava, P. M. (1989). Isolation and identification of Pseudomonas spp. from Schirmacher Oasis, Antarctica. Appl Environ Microbiol 55, 767-770.

Shivaji, S., Bhanu, N. V. \& Aggarwal, R. K. (2000). Identification of Yersinia pestis as the causative organism of plague in India as determined by $16 \mathrm{~S}$ rDNA sequencing and RAPD-based genomic fingerprinting. FEMS Microbiol Lett 189, 247-252.

Shivaji, S., Reddy, G. S. N., Raghavan, P. U. M., Sarita, N. B. \& Delille, D. (2004). Psychrobacter salsus sp. nov. and Psychrobacter adeliensis sp. nov. isolated from fast ice from Adelie Land, Antarctica. Syst Appl Microbiol 27, 628-635.

Shivaji, S., Reddy, G. S. N., Suresh, K., Gupta, P., Chintalapati, S., Schumann, P., Stackebrandt, E. \& Matsumoto, G. I. (2005a). Psychrobacter vallis sp. nov. and Psychrobacter aquaticus sp. nov., from Antarctica. Int J Syst Evol Microbiol 55, 757-762.

Shivaji, S., Chaturvedi, P., Reddy, G. S. \& Suresh, K. (2005b).

Pedobacter himalayensis sp. nov., from the Hamta glacier located in the Himalayan mountain ranges of India. Int J Syst Evol Microbiol 55, 1083-1088.

Smibert, R. M. \& Krieg, N. R. (1994). Phenotypic characterization. In Methods for General and Molecular Bacteriology, pp. 607-654. Edited by P. Gerhardt. Washington, DC: American Society for Microbiology.

Stackebrandt, E. \& Goebel, B. M. (1994). A place for DNA-DNA reassociation and $16 \mathrm{~S}$ rRNA sequence analysis in the present species definition in bacteriology. Int J Syst Bacteriol 44, 846-849.

Thompson, J. D., Higgins, D. G. \& Gibson, T. J. (1994). CLUSTAL W: improving the sensitivity of progressive multiple sequence alignment through sequence weighting, position-specific gap penalties and weight matrix choice. Nucleic Acids Res 22, 4673-4680.

Weeks, O. B. (1981). Preliminary studies of the pigments of Flavobacterium breve NCTC 11099 and Flavobacterium odoratum NCTC 11036. In The Flavobacterium-Cytophaga Group, pp. 108-114. Edited by H. Reichenbach \& O. B. Weeks. Weinheim: Gesellschaft fur Biotechnologische forschung. 